歯の咬耗度を含めた年齢予測モデルの作成

吉川和利* 宗高弘子** 山口立雄***

\title{
Establishment of age-predictive model including the degree of dental attrition.
}

\author{
Kazutoshi KIKKAWA* \\ Hiroko Munetaka** \\ Tatsuo Yamaguchi***
}

\begin{abstract}
In this study, a linear model was applied in order to predict chronological age on the basis of independent variables such as blood pressure ( SBP, DBP), maximal aerobic power ( MAP), some measures of physical fitness ( FLEX $=$ standing trunk flexion, BALANCE $=$ one foot balance with eye closed, SITUP = situps during 30 sec., FAT = estimated percent body fat from skinfolds thickness), and $\mathrm{DA}=$ dental age from Sugiyam 's estimation .

Sixty-seven males ( 18 to 60 years of age ) as subjects participated in this study.

The results of this study can be summarized as follows:

1) DA showed a fixed contribution for chronological age.

2) There was no relationship among dental attrition and physical fitness except SITUP.

3) As a result of stepwise regression analysis, the following model was established as optimal : $y=$ $36.3+0.424 \times$ DA $-0.994 \times \operatorname{SITUP}\left(R^{2}=0.613\right)$.

4) The stability of this model was confirmed according to the analysis of residuals.

5) The model containing all variables is as follows : $\mathrm{y}=31.3+0.42 \mathrm{x}$ DA $-1.08 \mathrm{x}$ SITUP $+0.112 \mathrm{x}$ $\mathrm{FLEX}+0.008 \times \mathrm{BALANCE}+0.036 \times \mathrm{MAP}-0.019 \times \mathrm{SBP}+0.103 \times \mathrm{DBP}-0.094 \times \mathrm{FAT}\left(R^{2}=0.634\right)$

\section{緒 言}

厚生省の報告する受療率の変遷を概観すると, 1955 年と 1995 年の相対比の上位を占める疾患に, 糖尿病, 脳血管疾患, 筋骨格系・結合組織の疾患, 高血圧性疾患，悪性新生物があげられる。これら の慢性退行性疾患と総称される疾患は，成人病・ 老年病のほか, 運動不足病・食源病あるいは生活

習慣病とも呼ばれるが，「ある特定の基礎疾患状 態」が，別の基礎疾患状態を派生させ，全身症状 として増悪化していく。すなわち閉塞的な構造を 持つ。我が国は，第二次大戦後に，世界に類をみ ない速度で, 長寿化を達成したとしても, こうし た閉塞構造をもつ疾患の増大は，個体に早すぎる 老化を生じさせ, 社会全体に活力の低下をも招来
\end{abstract}

*広島県立大学 Dept. of Physical Education, Hiroshima Pref. University, 562 Nanatsuka, Showbara, 727-0023.

**就実短期大学 Shuujistu Junior College, Nishikawahara,Okayama, 703-8258

***岡山大学教育学部 Faculty of Education, Okayama University, Tsushimanaka, Okayama, 700-0082 
しかねない，健康な長寿あるいは，正常な加齢は 等しく個人や社会の希求するところである。学問 として老化を扱う場合の大きな課題は, 老化遅延 策を見いだすことでもある.

第一に本研究での老化ということばの定義をし ておく.今堀和友 $(1984)^{12)}$ の生理的老化と病的 老化という分類に倣い，狭義の老化とは「年齢に 相対的に観察して，機能低下を生じていること」 と本研究では定義する。心身ともに必然的な事象 としての加齢に伴った変化があるとしても，余裕 力を持ち，若々しい活動力を有しながらの加齢は 少子・高齢社会に限らず，望まれるところであ る.

林知已夫 $(1981)^{7)}$ は心の老化制御に関し，「外 からの制御」（医療，社会・経済生活など政策 · 対策の問題)，「内からの制御」(自覚を促す，自ら 考え，務める）の二つが考えられるとしている。 心の制御に限らず, 最近の循環器疾患・糖尿病 ·

筋骨格系及び結合組織の疾患に代表される慢性退 行性疾患は，広く運動不足病と称され，これらの 疾患の増加は身体運動の必要性を意味している。 故に老化制御は, 教育学的あるいは体育学的課題 でもある。

したがって第二に，教育的な課題をしての老化 制御の方法論について触れておかねばならない. 岩崎 栄 $(1990)^{14)}$ は地域医療策定の基本的視点と して現実を的確に反映していること (reality), clientを含めた他者に理解されやすいこと (understandability), 測定しやすいこと (measurability), 厚生行政や学校 ·社会教育で行為化しやすく (behaviorability), 達成可能性を有すること (achievability)であるとしている，とりわけ，老化水準 が被験者にとって「理解しやすい」指標で表現さ れること，あるいは「加齢の水準を的確に示し， 測定しやすい」变数の採択について検討すること が求められる.

第三に老化を探る方策のうち，まず，デー夕を 扱う手法について検討する。姿勢や顔貌のほか, 歩行などの動作によって同一年齢でも「老けて」 評価される場合と「若々しく」評価される場合も
あるという個体差が存在する以上，統計的に老化 を評価することができる，さらに我々は肌の解， ツヤや頭髪などから他人の年齢を推定しているこ とがよくある，身のこなしなども同様であり，歳 をとることの結果でおきる種々の身体状況から原 因としての年齢に立ち帰る意識的，無意識的な様 式は, 統計手法のうち, 外的基準（従属变数, 被 説明变数）を有する場合に相当する.

第四に老化を表現する指標について述べる．田 中 $(1998)^{32)}$ が指摘するように，心身の状態や機能 を表す概念として身体活動（運動）・体力・健康の 三者には重複する部分が大きく，五島 $(1980)^{5)}$ は 分子生物学に代表されるミクロはレベルより，大 まかな視点の方が都合がよいとし，また吉川 $(1974)^{33)}$ は個別臓器だけではなく「個体としての まとめが必要」と述べている．また田中 $(1998)^{321}$ は老化過程における個人差を正しく理解するため には，生理的な老化の進行状態からみた概念規定 の中で検討を進める必要性を述べている。こうし た見解は，先に述べた統計手法のうち，多变量を 同時に扱う多变量解析に符合する.

第五に，主として体力医学や教育医学の中で扱 われている加龄指標に関連する变数が属する領域 を概観する．中村とその共同研究者たちは，動物 実験に並行して，人間ドックの検査值を用いた統 計的研究を精力的に展開している. 田中とその共 同研究者たちは, 機能関連体力 (skill-oriented physical fitness)に対比させた健康関連体力 (health-oriented physical fitness) の有効性を提言 している ${ }^{19)} 30$ 31) 32).これは Gutin, B. (1980) ${ }^{6)}$ を 嚆矢とする「dynamic health」の概念に導入され ている変量に相応し，この中では，全身持久性体 力, 筋力 - 筋持久性体力, 柔軟性体力, 身体組成 が総合されている.

こうした第四，第五の事項から，日常の健康を 志向した老化指標の策定にあっては，少なくとも， 全身持久力・筋肉の力や持久性，骨・筋肉・結合 組織全般の柔軟性などの領域からの変量を総合的 に扱い得る合成変量とそのための分析手法が要求 されることになる。 


\section{研究の目的}

老化研究におけるこれらの問題を整理すると現 今の研究課題が自ずと明らかになる.

まずもって，老化現象あるいは老化水準が適切 に把握されねばならない。そのための最大の課題 は, 加齢現象の本体, 実質 (Reality) を適切に （妥当性をもって）表現する指標（marker of ageing）を設定することである. Cowdry（1952） は細胞の老化を記載するために, 特性の異なる 種々の生体内細胞をその分裂能力と分化能力によ って（1）増殖性分裂細胞, (2) 分化性分裂細胞, （3）可逆性分裂終了細胞，（4）固定性分裂終了細 胞の 4 群に分類した (東京化学同人生化学辞典). このうち，皮膚の幹細胞など（1）に分類される細 胞は，その寿命が短く，それ故に加齢变化が反映 され難い。これが (2)，(3) となるに従って加齢変 化が反映されやすくなり，とりわけ（4）に分類さ れる神経細胞や心筋細胞などは高い分化能力をも っており，再生できないために，加齢変化を十分 に受け易い細胞であることが知られている。した がって，老化を検討するためには，加齢変化が顕 著な高次レベルに分類される細胞を対象とする必 要がある。

Cowdry（1952）の 4 水準区分において，歯の咬 耗状態は, 心筋・運動ニューロンとともに, 最も 年齢変化に忠実な指標と考えられている. 同時に 歯には辞書の上で年齢そのものを意味しており， また, 歯序, 歯列といわれるように歯牙の咬耗度 は身体機能の老化を適切に反映した指標であると 考えられる。歯の形態や機能に関した指標は個別 にその加齢変化について検討されることはあって も, 心身の余裕力ゃ体力との関連を検討されるこ とは少ない。

また, 教育学的な課題とする以上, client, 受 検者に対して, 情報のフィードバックがわかりや すいものであること, 身体運動などを媒介として 行為化し得る指標づくりが図られねばならない.

本研究では, 一定以上の年齢効果を持ちながら, 個別領域的にしか扱われなかった歯の咬耗度を説 明 (独立) 変数として考虑しつつ, 心身の加齢現
象を総合的かつ適切に捉えるための年齢予測モデ ルの設定を検討する。

\section{研究方法}

【被験者】中山間地域に居住・勤務する男子 67 名 （18～60 歳，20 歳代以下 30 名，30 歳代 18 名，40 歳代 8 名, 50 歳代以上 11 名）が被験者として本 研究に参加した。被験者には文書により研究の趣 旨・目的・内容を説明し，同意・了解を得た上で 研究を実施した。

【検査項目】基礎体力・健康度（以下，フィットネ スと呼ぶ）の検査項目は 30 秒間の連続上体おこし (SITUP)，立位体前屈 (FLEX), 閉眼片足立ち (BALANCE), 12 分間 4 分ごとの負荷漸増法によ って心拍数から推定した体重あたり最大酸素摂取 量 (MAP), 安静時の最高・最低血圧 (SBP, DBP), 皮脂厚から長嶺・鈴木 (1964), Brozek et al. （1963）の式に従って求めた体脂肪率（FAT）であ った。また 28 本の歯牙の咬耗状態を杉山ほか $\left.(1986)^{27)} 28\right)$ にならって苗科医師が診査し，5段階 評定した。この場合，「歯種が異なればその形あ るいは咬合の状態が異なるので，咬耗を一椂に分 類することは困難である」が，分類基準は「 $1=$ エナメル質の摩耗の局面が狭い範囲で独立してい る場合」,「2 =エナメル質の大部分が磨耗してい る場合」，「3=象牙質の磨耗が進んで，部分的に 露出している場合」，「4=象牙質のかなりの部分 が広くあるいは強く摩耗している場合」，「5＝欠 如している場合」までの 5 段階をあげている ${ }^{27)}$. これらの係数 (数值)によって個体 (被験者) の 「歯科的年齢」を算出することで健康度指標開発 の新たな視点が可能となる。

【統計解析】1）被験者の歯牙咬耗度を診査值の 5 は 4 に変換後, 杉山ほか $\left.(1976,1986)^{27)} 28\right)$ が 提示した 28 本の歯牙咬耗度による年齢予測式 $(\mathrm{y} 1$ $=20.0+1.30 \times \mathrm{U} 1-0.09 \times \mathrm{U} 2+2.58 \times \mathrm{U} 3-0.82 \mathrm{x}$ $\mathrm{U} 4+2.39 \times \mathrm{U} 5-0.16 \times \mathrm{U} 6+1.12 \times \mathrm{U} 7+0.41 \times \mathrm{U} 8+$ $0.25 \times \mathrm{U} 9+0.86 \times \mathrm{U} 10+0.29 \times \mathrm{U} 11+0.04 \times \mathrm{U} 12+$ $0.72 \times \mathrm{U} 13+2.75 \times \mathrm{U} 14+0.86 \times \mathrm{L} 1-0.80 \mathrm{x}+1.14 \mathrm{x}$ $\mathrm{L} 3+2.83 \times \mathrm{L} 4-1.64 \times \mathrm{L} 5-0.69 \times \mathrm{L} 6+1.27 \times \mathrm{L} 7-$ $0.45 \times$ L8 $-0.12 \times$ L9 $+0.2 \times$ L10 $-0.04 \times$ L $11-0.49$ 


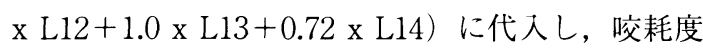
年齢を求めた。ここでU.は上顎左端（第 2 大臼歯） から右方向に右端までを示し，L. は下顎の右端か ら左端までを示している。

2 ）咬耗度年齢やフィットネス変数を独立変数 とした歴年齢予測モデルの作成を試みた。

\section{結 果}

\section{1 ) 基本統計量と相関行列の算出}

Table-1には暦年齢 $(\mathrm{CA})$, 歯牙咬耗度年齢 (DA) および各フィットネス変数の平均值, SD と 变数間相関係数を示している. 独立变数間の相関 係数が高い場合, 得られた偏回㷌係数の值が不安 定になる点, すなわち多重共線性が発生する ${ }^{2)}$. この $8 \times 8$ 相関行列の固有值は $\lambda_{1}=2.25, \lambda_{2}=$ $1.62, \quad \lambda_{3}=1.11, \quad \lambda_{4}=0.92, \quad \lambda_{5}=0.76, \quad \lambda_{6}=0.68$, $\lambda_{7}=0.58, \quad \lambda 8=0.55, \quad \Sigma(1 / \lambda)=11.9$ となった これは最小固有值が 0.01 以下であったり, 固有值 逆数の総和が独立变数個数の 5 倍を越えるもので はなく，仮に全变数から成る重回帰モデルを想定 した場合の多重共線性発生基準 ${ }^{2)}$ には合致してい ない.

さて, CA と DA の間には, 0.609 の相関係数が 得られた。しかし, 両者間の差は 10 歳と大きか った．個別フィットネス変数のうち，CA との相 関係数が有意なものは $\operatorname{SITUP}(-0.642)$ であり, SITUP は，また，DA との相関係数 $(-0.379)$ が 有意な唯一の変数であった.

\section{2 ) 線形年齢予測モデルの作成}

フィットネス変数とともに DA を独立変数とし た年齢予測モデルを作成した。变数を有意なもの から順に投入していく变数増加方式のステップワ イズの重回帰式作成を行った。Table-2には变数 投入ごとの情報統計量を示している。変数の投入 順は SITUP, DA, DBP, FLEX, FAT, BALANCE, MAP, SBPとなった.

これらの逐次変数を増加させたモデルのうち, AIC による変数選択の結果では $\mathrm{y}_{2}=36.3+0.424 \mathrm{x}$ $\mathrm{DA}-0.994 \mathrm{x} \operatorname{SITUP}\left(\mathrm{R}^{2}=0.613\right)$ が最適モデルと なった。または, Mallows による Cp 統計量も同 様であったが, SIC (Schwarz Information
Criterion) ${ }^{17)}$ では, DBP を加えた 3 変数からなる モデルを採択することになった。 また，すべての 変数を含んだモデルは, $\mathrm{y}_{3}=31.3+0.42 \mathrm{x} \mathrm{DA-}$ $1.08 \times$ SITUP $+0.112 \times$ FLEX $+0.008 \times$ BALANCE + $0.036 \times \mathrm{MAP}-0.019 \times \mathrm{SBP}+0.103 \times \mathrm{DBP}-0.094 \times$ FAT となった $\left(R^{2}=0.634\right)$.

\section{3 ) 残差分析}

予測值と歴年齢の差, すなわち残差は誤差項に 関する諸仮定への違背 (violation)を検討するため に重要な情報源である．y 2から得た残差の標準 偏差は 7.83 となった。また, 残差分布の尖度 (kurtosis) は, 0.211, 歪み度 (skewness) は0.559 となった，標準化残差を縦軸に，予測年齢を横軸 にした平面を構成し，残差分析を実施した結果を Fig.-1として示す.

\section{考 察}

1) 線形モデルの妥当性について

本研究では, 高次レベルの变数である歯牙, 筋 肉や骨格系が関与する運動・動作を利用した基礎 体力, 血圧と年齢との関連を検討した。フィット ネス変数と CA との関連性は低かったが, 歯の咬 耗度に基づく要因を含めた予測式を作成した時, 相当に優れた歴年齢予測が可能となった。

運動パフォーマンスや四肢・全身の筋力などは 系としてのヒトの統合性と測定の現実性を考慮し た時，また老化制御として行為化する時にも適切 であり，老化モデル作成のための合理的な指標と して捉えることができる。

従来, 体育学・体力学における年齞予測モデル 設定研究の多〈18１9） 23）24）25）30)では, 予測の妥 当性を主としてそのモデルの重相関係数 (寄与率) によって得てきている。これらのうち, 田中ほか $(1990)^{30)}$ は 106 名の女子 $(30 \sim 72$ 歳)について 11 個の身体測定值（反復横跳び, 閉眼片足立ち, 腹囲, 収縮期血圧, 血液中の脂質 ( TC $\cdot \mathrm{LDL}$ ・ $\mathrm{TG})$, ヘマトクリット值, 最大酸素摂取量, 肺換 気量）の主成分得点を歴年齢分布に変換した活力 年齢を求め, 歴年齢との間に 0.69 の相関係数を得 ている。ささら線形モデル固有のエラーを回避す るために修正式を求めた結果, 修正予測年齢と歴 
Table-1 : 年柃と独立変数の平均値, SDおよび相関係数行列

\begin{tabular}{|l|r|r|r|r|r|r|r|r|r|}
\hline & Ch. AGE & DENT AGE & SITUP & FLEX & BALANCE & MAP & \multicolumn{1}{l|}{ SBP } & DBP & FAT \\
\hline MEAN & 34.3 & 44.8 & 20.6 & 5.6 & 30.9 & 39.7 & 136.7 & 84.1 & 18.1 \\
\hline SD & 11.1 & 11.1 & 5.6 & 7.9 & 45.2 & 10.4 & 18.8 & 12 & 5.6 \\
\hline Ch. AGE & 1 & 0.609 & -0.642 & -0.141 & 0.095 & -0.179 & 0.016 & 0.175 & 0.131 \\
\hline DENT AGE & & 1 & -0.379 & -0.205 & -0.033 & -0.214 & 0.059 & 0.103 & 0.065 \\
\hline SITUP & & & 1 & 0.305 & -0.071 & 0.261 & -0.052 & -0.057 & -0.377 \\
\hline FLEX & & & & 1 & 0.108 & 0.195 & 0.036 & 0.019 & -0.135 \\
\hline BALANCE & & & & & 1 & 0.052 & 0.012 & 0.201 & -0.131 \\
\hline MAP & & & & & & 1 & -0.285 & -0.321 & -0.493 \\
\hline SBP & & & & & & & 1 & 0.623 & 0.268 \\
\hline DBP & & & & & & & & 1 & 0.177 \\
\hline FAT & & & & & & & & & 1 \\
\hline unit & yrs. & yrs. & times & $\mathrm{cm}$ & sec. & $\mathrm{ml} / \mathrm{min} / \mathrm{kg}$ & $\mathrm{mmHg}$ & $\mathrm{mmHg}$ & $\%$ \\
\hline
\end{tabular}

Ch. AGE=Chronological Age;DENT AGE=Dental Age by Sugiyama's method;

SITUP=Situps during 30 sec.; FLEX=Standing trunk flexion;

BALANCE=One foot balance with eye closing; MAP=Maximal oxygen intake;

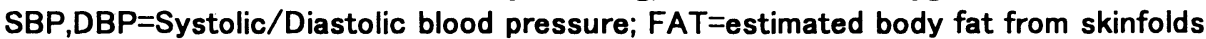

Table-2 : ステップワイズ方式重回帰分析での選択変数と諸統計量

\begin{tabular}{|r|l|r|r|r|r|}
\hline step & Variable & sqr. R\% & Cp & AIC & \multicolumn{1}{l|}{ IIC } \\
\hline-1 & SITUP+ & 45.6 & 21.3 & 529.7 & 525.6 \\
\hline-2 & DAt & 61.3 & 0.47 & 510.1 & 505.1 \\
-3 & DBP+ & 62.1 & 0.856 & 510.8 & 504.8 \\
-4 & FLEX+ & 62.7 & 1.999 & 511.9 & 504.8 \\
-5 & FAT+ & 63.1 & 3.396 & 513.2 & 505.1 \\
-6 & BALANCE+ & 63.26 & 5.199 & 514.9 & 505.9 \\
\hline-7 & MAP+ & 63.34 & 7.077 & 516.8 & 506.7 \\
\cline { 2 - 6 } & SBP+ & 63.4 & 8.99 & 518.7 & 507.6 \\
\hline
\end{tabular}

sqr. $R \%=$ Squared $R$ (multiple correlation coefficient) $\times 100$

$C_{p}=$ Mallows' $C p ; A I C=A k a i k e ' s$ Information Criterion;

SIC=Achwarz Information Criterion;

年齢が 0.81 の相関を示したと報告している. 李・ 松浦・田中 $(1993)^{19)}$ は 184 名の男子について 6 個 のスポーツ適性の変量と酸素摂取量 (乳酸閾値 ·

最大值）を用いて，同様な統計手順を行い，主成 分得点と歴年齢の間に 0.88 , 修正予測年齢との間 に 0.90 の相関をそれぞれ得ている。また，本邦に おいて，こうした手順の先駆的な役割を果たした Nakamura et al. (1998) ${ }^{24)}$ は, 血液生化学検查值 データについて同様な手順により線形な予測モデ ルを得ている。
いうまでもなく, 回帰モデルでは自由度 (標本 数と独立変数との差) が低減するだけ, 寄与率は 高まって行く必然性をもつ。それ故に，寄与率の みで，モデルの妥当性をいうことはできない，多 くの研究者が交差妥当性の作業を導入することに よって，モデル自体の妥当性を確認しょうとして いる. しかし, 老化指標として被験者へのフィー ドバックや処方など行為化を必要としたり，測定 の容易さ・簡便さを考慮したりすることが必要な 一方, 主成分得点化などは相当に複雑な計算を含 


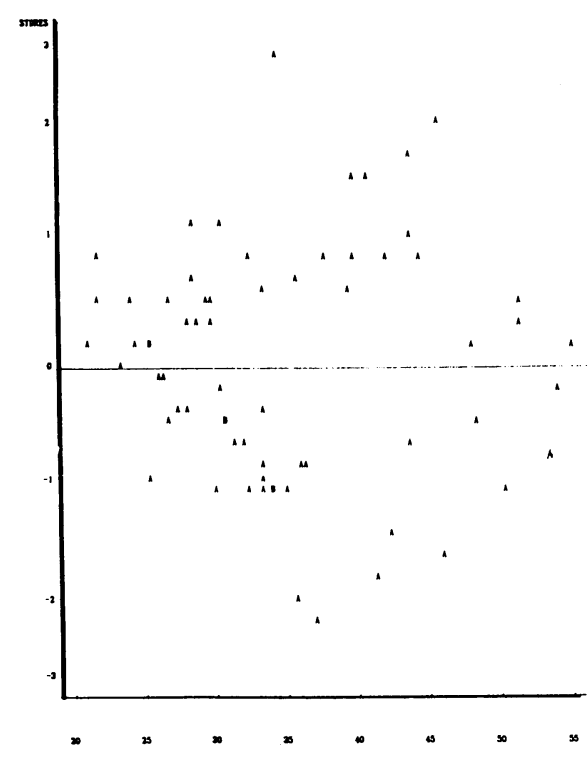

Fig. 1 : 標準化残差（縦軸）と予測年齢

むものと考えることもできる．

本研究では自由度の低減と寄与率のみせかけの 上昇を回避する手段として, 複数の情報量基準を 導入した。この結果, 歯の咬耗度は重要な変数と して位置づけられた。その一方で, Gutin, B. $(1980)^{6)}$ や田中ほか $(1990)^{30)}$ が重視する全身持久 性 ( MAP) や躯幹・関節の柔軟性 ( FLEX), 体組 成（FAT）は必ずしも，有効な変数とは位置づけ られなかった。ただし，AIC で選択された 2 変数 (SITUP, DA)のみのモデルからの残差と MAP, FLEX, FAT, SBP, DBP, BALANCE の全変数から なるモデルからの残差の差は $d_{12}=-0.241$ と小 さく, 有意でなかった $(t=1.199, P<0.23)$.ま た， 2 つの残差の相関係数は $\mathrm{r}=0.973$ と高く, 両モデルは類似していると考えられた。したがっ て，2つのモデルには有意な差はなく，情報縮約 の面からは, 少変数モデルが採択されるべきであ ろう.

\section{2 ) モデルの精度の検討}

線形回帰での残差診断を試みた結果, 2 変数モ デルの残差基本統計量は尖度 (kurtosis) $=0.211$, 歪み度 (skewness) $=0.559$ となって, 残差分布の 正規性を満足できると考えられる。また，標準化 残差のうち，絶対值が2.5を越える観察值は 1 例し
かなかった。予測值に対する標準化残差も, 平均 值ゼロの周囲にランダムな散らばりを示し, 特定 の偏りがあるとはいえなかった。したがって，以 上の点から，ここで提示したモデルの信頼性は， ほぼ問題が無いと考えて良いと判断される.

さらにAICによって選択されたモデルに含まれ る変数 (SITUP, DA)の相関係数行列から算出され た固有值は $1.642,0.358$ であり，多重共線性の 存在については否定して良いであろう。この多重 共線性への対処については (1) ステップワイズ重 回㷌分析に有効性を認める場合もあるし，(2) リ ッジ回帰分析にその有効性を認める場合もある2

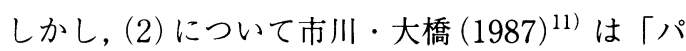
ラメータの事前分布の平均を 0 においたベイズ流 (Bayesian)の推定法と等価」であり，事前情報が あるのなら定式化に盛り込むべきであるとして否 定的な見解を述べている，すなわち，本研究で用 いた手法ステップワイズ重回帰分析によって多重 共線性への対処を図ることができ，実質的に多重 共線性による係数の不安定性も存在しなかったこ とになる。

\section{3 ）年齢予測における歯の咬耗度の意義}

漢字辞書には，人間の年齢段階を表す用語とし

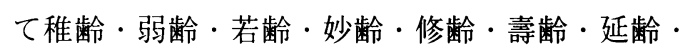
老齢・高齢・暮齢・䅡齢などや龆歳・䶖童（=歯 の抜け替わる年齢。その年齢の子ども）があげら れている。藤堂明保編：学研漢和大辞典では「歯」 には「馬の歯をみてその年がわかる」，「順番に並 ぶ」という動詞的意味づけがあり，同様な意味で

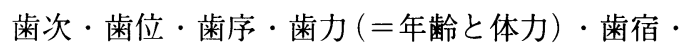
歯算・歯徳といった歯にまつわる用語があげられ ている.「齢(ヨワイ)」が「歯」ヘンをもって構 成されることを考え合わせても語源的に歯は年齢 そのものを意味しており，成長や老化を研究する 立場からは大いに関心が寄せられるべき対象であ る。発育発達研究では骨年齢と同様に歯牙年齢を 「正常な成長範囲」にあるか否かに関して利用し てきたが，米国で発刊されている成長・老化研究 の雑誌「Growth, Development, and Aging」誌に は従来から「歯の形態的」成長を扱った論文がか なり多い. 
アリストテレスは動物誌（島崎訳，岩波文庫） のなかで「ロバの年齢推定は歯で判定できる」と 述へ，動物の老若は顎の皮䖉をめくり返した時の 戻り具合いでわかるとも記している。すなわち熊 (犬飼・門崎, 1972) 13) やアカネズミの歯から年 齢推定を行ったもの (正田・村山，1980) ) $^{8}$ など がみられる。またヒトを対象としたときに法医学 や人類学では歯の咬耗度によって死体などの年齢 推定を相当に古くから行ってきている.

杉山高一ほか「歯の咬耗度による年齢推定に関 する重回帰分析」(1979) ${ }^{27)}$ は暦年齢を従属変数に して歯の咬耗度から予測推定しようとする重回㷌 分析を線形およびカテゴリカル的に実施してい る。すなわち上左から上右までに番号 (1)，、, (14)，下右から下左までに(15)，‥，(28）を割り 当て, 赤池氏の情報量規準 $A I C$ を適用した変数選 択により最適な方程式を以下のように作成してい る。だたし，杉山の原著論文には，定数項の記載 がなく, 偏回帰係数のみを以下に示す $\left(R^{2}=0\right.$. 727 ).

$\mathrm{y}=2.36 \mathrm{x}(1)+1.85 \mathrm{x}(8)+2.30 \mathrm{x}(10)+1.76 \mathrm{x}(12)$ $+3.12 \times(14)+2.07 \times(15)+0.95 \times(22)-0.15 \times(24)+$ $1.12 \mathrm{x}(25)+0.23 \mathrm{x}(26)$;

また竹井哲治「歯の咬耗による年齢推定」(1971) 29) でも同様にカテゴリカル重回帰を行った結果を 報告している，しかし杉山ほか $(1986)^{28)}$ は咬耗度 のみによる予測式で 0.783 以上の寄与率を得てお り, 本研究での CA との相関係数からみれば, 年 齢予測が十分に達成されているとはいい難い，ま たDA と CA には10歳以上の差が存在することに なった。このような結果は杉山モデルとの約 20 年の cohort 差, 年齢分布の差, 杉山の研究で性別 が不明である点なども理由であると考えられる。

4 ) 身体的老化指標の提言上の課題

本研究は吉川ほかの従来の研究と同様に,「老 化制御」に活用して行くことも考えられる。本研 究を通じて年龄予測に関する歯牙や骨の状態をも つ有効性は不十分ながら指摘できる。本研究で提 示したモデルからの予測值を歴年齢との比（相対 老化度)として利用すれば，歴年齢相応のフィッ トネスを有しているのか, 若々しいのか, 老けて
いるのかを評価できることになる，さらに，生活 要因 (運動や栄養など) と相対老化度との関連を検 討する作業を吉川ほか $\left.(1989,1992)^{15)} 17\right)$ として 行ってきた。

確かに老化度を示す指標 ( marker of aging ) を 探索することは, 老年学研究の最大にして究極の 課題である。しかし，この指標が明らかでなく， また老化自体が個体内差をもち，個体差も大きい 現象である以上, 統計的研究が有効であると考え ている．事実．Kikkawa（1989）ではこうした試 みがいくつかの研究において行われていることを 概覧した ${ }^{15)}$.また，古典的になった Furukawa et al. $(1970)^{3)}$, 古川 $(1976)^{4)}$ のモデルや Hofecker, G. et al. $(1980)^{9)}$ の知見, 歴年齢を従属変数, 主 成分得点を独立变数とした最近の Nakamura et al. $\left.(1988)^{24)} 25\right)$ の生物学的年齢モデルや田中ほか $\left.(1990 ， 1992)^{30)} 31\right)$ の活力年齢モデルも「多くの 変量や合成值を歴年齢に収束させる」ことを同様 に意識している。

歴年齢との比を用いる有効性の第二の理由は以 下の点である. 準実験的な研究の場合, client や 受検者, 被験者へのフィードバック, 受け入れ易 さは，また不可欠な要件でもある。本研究で用い た変数の多くは, 文部省スポーツテストとして, あるいは一般的な内科検診の場で広範に知られて いるものである。また，歯の咬耗度も比較的に理 解を得やすい指標であると考えられる。 それ故に， client によるフィードバック情報の理解や処方と しての運動実践, 測定の容易さや簡便さについて の利点を有している。むしろ，筆者らは「生理的 年齢」の提言にあたって, 寄与率が $50 \%$ を前後 するのみであるという歴年齢に対するフィットネ ス変数の感受性の低さを経験してきた。こうした モデル自体の妥当性(あてはまりの良さ)を高める ことは，焦眉の急を要する課題である.

また歴年齢と DA との相関係数はほかのフィッ トネス変数に比べて，かなり高いものであるが, フィットネス変数を含めた重回帰分析の結果とし て重相関係数はそれほど高くはならなかった。確 かに身体機能と歯牙の咬耗度との間には特に指摘 できるような関係はなかった。この点からすると， 
DA とフィットネス変数を並行的に独立変数とす るには，無理があると考えられるかもしれない． ただし，歯牙の咬耗度はCowdry (1952)の分類で 老化を的確に表し得る代表的な变数であり,これ は従来の体力・体育学的研究で取り扱われること は少なかった，歯牙の状態は種々の身体症状と不 可欠の関係にあることが知られており ${ }^{16)}$, むしろ フィットネス変数の設定や構成 (バッテリー) に ついて検討すべきかもしれない，同時に Rohner et al. $(1983)^{26)}$ は 1 年間の歯間部の歯槽骨吸収に ついて 70 歳以上になると, 70 歳未満の者の 4 倍 になるとしている。すなわち歯の咬耗度は70 歳 以上において，より顕著になり，おそらく身体機 能の老化との関係も, より深くなることが推定で きる. 本研究の対象者は高齢者の分類には属さな い集団であり，さらに幅広い年齢層を含んだ被験 者集団についての考察が必要であろう.

一方で, 運動ニューロンを反映させようとした 運動パフォーマンス系の変数の寄与は十分でな く, また, 心臓血管系の変数 (SBP, DBP) や全身 持久系の変数 (MAP) にしても統計的な基準から すれば，十分に寄与しているとはいえなかった. これらに関しては, 例えば運動負荷時の血管動態 を観察すること, 最大酸素摂取量については間接 法でなく直接法によりオールアウトまでの負荷設 定を行うことなどが必要かもしれない.

また J. Gerontol. など老年学に関係した学術誌 では, 例えば Hollak et al. $(1989)^{10)}$, Alexander et al. $(1992)^{1)}$, Ming-Hsia and Woolacott (1994) 21) 22) などのように老化の測度として振動感覚, 動的平衡性などを扱った研究が多く, 普遍的な老 化を探る変数として重視されていることに大いに 留意せねばならない. 運動ニューロンの加齢状況 に関してはこれらの点も考慮されるべきかもしれ ない。モデルのあてはまりを補強する上で知覚適 性に関係した変数の追加採用も，また必要である と考えている.

\section{要約と課題}

独立変数として血圧值など循環機能や基礎的な フィットネス変数, および歯の咬耗度の測定值を
用い，歴年齢を予測する線形モデルの作成を試み た. 被験者として男子 67 名 $(18 \sim 60$ 歳, 20 歳代 以下 30 名, 30 歳代 18 名, 40 歳代 8 名, 50 歳代 以上 11 名) が本研究に参加した. 結果と課題は以 下のようにまとめられる。

1 ）歯牙の咬耗度は年齢に対して一定の寄与を 示した. 身体機能と歯牙の咬耗度との間に は特に指摘できるような関係はなかった。

2 ）情報規準 $A I C$ や Mallowsによる $C p$ 統計量 を手がかりに有効な変数を選択しながら進 めたステップワイズ重回帰分析の結果, 得 られた $\mathrm{y}_{2}=36.3+0.424 \mathrm{x} \mathrm{DA}-0.994 \mathrm{x}$ SITUP $\left(R^{2}=0.613\right)$ が最適な線形モデル となった。

3 ) このモデルは残差分析でも, 問題は無いと 考えられ, その有効性と安定性が示唆され た。

4 ) すべての変数を含んだモデルは, y3 $=31.3$ $+0.42 \times$ DA $-1.08 \times$ SITUP $+0.112 \times$ FLEX $+0.008 \times$ BALANCE $+0.036 \times$ MAP $0.019 \times \mathrm{SBP}+0.103 \times \mathrm{DBP}-0.094 \times \mathrm{FAT}$ となった $\left(R^{2}=0.634\right)$.

5 ) 運動パフォーマンス系の变数の寄与は十分 でなく, また, 心蔵血管系の変数 ( SBP, DBP）や全身持久系の変数 (MAP) にして も統計的な基準からすれば，十分に寄与し ているとはいえなかった。

6 ）歯の咬耗度が顕著になる高齢集団では, フ イットネス機能との関係も含めて, かなり 異なった様相のモデル提示の可能性があ る。さらに幅広い年齢層を含んだ被験者集 団についての考察が必要であろう.

\section{文 献}

1) Alexander, N., Shepard, B. N., Gu, M.. J. Schultz A. (1992) : Postural control in young and elderly adults when stance is perturbed : kinematics. J. Gerontol. 47 : M79-M87.

2) チャタジー, プライス (1990) : 回帰分析 の実際, 新曜社212-236. (Chatterjee S., B. 
Price, Regression analysis by example. John Wiley and Sons Inc., 1977)

3 ) Furukawa, T., Inoue, M., Kajiya, F., Inada, H., Takasugi, S., Fukui, S., Takeda, H., Abe, H. (1975) : Assessment of biological age by multiple regression analysis. J. Gerontol. 30 : 422-434.

4 ) 古川俊之 (1976) 寿命モデル. 数理科学 14 (1) : 43-55.

5 ) 五島雄一郎 (1980): 生理生化学臨床検査 に基づいた加齢変化. 日本老年医学会雑誌 $16: 91-101$.

6 ) Gutin, B. (1980) : A model of physical fitness and dynamic health. J. Physical Education and Recreation 51(5): 48-51.

7 ) 林 知已夫 (1981）：心にとって加齢とは 何か, 太田邦夫, 阿部 裕, 古川俊之編 高齢化社会の構造. サイエンス社, 176196.

8 ）正田 務, 村上興正 (1980):アカネズミ の齢推定. 日本生態学会雑誌 $30: 109$ 116.

9 ) Hofecker, G., Skalicky, M., Kment, A., Nidermuller, H. (1980) : Models of the biological age of the rat. I. A factor model of age parameters. Mechanisms of Ageing and Development 14:345-359.

10) Hollak, F.B., Shupert, C. L., Mirka, A. (1989) : Components of postural dyscontrol in the elderly. Neuro-Biology of Aging 10 : 727-738.

11）市川伸一, 大橋靖雄（1987）：SASによる デー夕解析入門. 東京大学出版会, 162165.

12）今堀和友 (1984)：「老人らしい」とはど ういうことか. 現代化学, No.164, 14-19.

13）犬飼哲夫, 門崎充昭 (1972) : ヒグマの歯 のいわゆる年輪による年令測定に関する研 究 (予報) 。日本応用動物昆虫学会誌 16 (3) $: 148-151$.

14）岩崎 栄（1990）: 地域医療の基本的視座.
ベクトルコア社, 1-14.

15) Kikkawa, K. (1989) A statistical approach for physical senility/aging and its control. In M. Kaneko (ed.) The aged, disabled, and industrial worker, Human Kinetics Co., 1-5

16）吉川和利, 村津和正, 藤野武彦, 安田 稔 （1993）：歯科機能の老化と体格・体力の関 連度について。広島体育学研究 $19: 41$ 52.

17）吉川和利（1991）：身体機能加齢変化の重 回帰分析と老化要因の分散分析: 循環機 能 - 身体機能からの歴年歯推定と生活習慣 の影響. 広島体育学研究 $17: 62-76$

18）木村みさか, 森本好子, 寺田光世(1991)： 都市在住高齢者の体力診断バッテリーテス トによる体力, 体力科学 40:455-464.

19）李 美淑, 松浦義行, 田中喜代次(1993）: 中高年男性の体力年齢の評価. 体力科学 $42: 59-68$.

20) Manchester, D., Woolacott, M., ZederBauer-Hylton, N., Mario, O. (1989) : Visual, vestibular and somatosensory contributions to balance control in the older adult. J. Gerontology 44 : M118-M127.

21) Ming-Hsia, Hu and Woolacott, M. H. (1994): Multisensory training of standing balance in older adults: I. Postural stability and one-leg stance balance. J. Gerontology 49 (2) : M 52-M 61.

22) Ming-Hsia, Hu and Woolacott, M. H. (1994): Multisensory training of standing balance in older adults : II. Kinematics and electromyographic postural responses. J. Gerontology 49 (2): M62-M71.

23）中村榮太郎, 木村みさか, 永田久紀, 宮尾 賢爾，小関忠尚（1982）：種々の生理機能 にもとづく老化の指標としての生物学的年 齢の推定 (男子の場合). 日本衛生学雑誌 $36: 853-862$.

24) Nakamura, E., Miyao, K., Ozeki, T. (1998) : Assessment of biological age by principal 
component analysis. Mechanisms of Ageing and Development $46: 1-8$.

25) Nakamura, E., Moritani, T., Kanetaka, A, A. (1988): Effects of habitual physical exercise on age in men aged $20-85$ years as estimated using principal component analysis. European J. Applied Physiology, 73 (5) : 410-418.

26) Rohner F., Cimasoni G., Vuagnat P. (1983) : Longitudinal radiographical study on the rate of alveolar bone loss in patient of a dental school. J. Clinical Periodontology 10 (6) : 643-651.

27）杉山高一, 尾崎 公, 牛澤賢治, 清水正利 （1979）：歯の咬耗による年齢推定に関する 重回帰分析. 応用統計学 5(3):123-128.

28）杉山高一 (1983) : 多变量デー夕解析入門. 朝倉書店, 104-136.
29）竹井哲治（1971）歯の咬耗による年齢推定. 日法医誌，24 (1)：4-17.

30）田中喜代次, 松浦義行, 中塘二三生, 中村 榮太郎（1990）：主成分分析による成人女 性の活力年齢の推定. 体育学研究 $35: 121$ 131.

31) Tanaka, K., Watanabe, Y., Hiyama, T., Takebe, M., Yoshimura, T. (1992) : Changes in vital age of CHD patients following a supervised aerobic conditioning program. J. Jpn. Atherosclerosis Soc. 20 :567-603.

32）田中喜代次（1998）：多くの情報を融合し た体力・健康指標の限界と展望. 第 53 回 日本体力医学会大会予稿集 p. 134.

33）吉川政巳（1981）：老化度・健康度をどう 測定するか. 内科 48:729-735.

1999年 4 月 3 日受付 同年 6 月 6 日受理 